\title{
Jarred baby food purchasing habits among mothers of infants in Hungary, and the features of baby food labels
}

Katalin Lipták Consumers are becoming more conscious

University of Miskolc of product selection owing to the vast amount Institute of World and Regional of information available on the Internet. Economics, This attitude is particularly apparent towards Hungary food products sold in the market. The healthy E-mail: lifestyle trend has led to the appreciation liptak.katalin@uni-miskolc.hu

Noémi Hajdú

University of Miskolc Institute of Marketing and

Tourism,

Hungary

E-mail: margn@uni-miskolc.hu of nutrition facts labels on packaged foods. Information, such as guideline daily amounts (GDA), product components, manufacturer details, expiration date, etc. influences our purchase decisions. By listing the ingredients and providing the recommended intake levels, these labels especially play a key role in influencing the purchasing decisions of consumers regarding first food options. This is particularly true for a growing number of mothers whose infants have intolerance to various foods (containing dairy products, eggs, etc.).

The purpose of this study is to examine the information content on the labels of jarred baby foods available from different manufacturers in Hungary with the help of a questionnaire survey and to determine whether there is a difference between the purchase behaviour of mothers and the purchasing tendencies. In the view of the demographic problem of aging in Europe, it has become important to focus on the kind of foods consumed by the population. In this context, it is crucial to examine the first foods of babies which set up the foundation of their health for the rest of their life. The authors examine the nutrition labelling of jarred

Keywords: baby foods. The fields of economics, marketing, food labelling, and consumer protection law are combined jarred baby foods, in this paper because they are key to examining consumer behaviour consumer rights in the studied context. 


\section{Introduction}

Nielsen estimated the global baby food and formula sales to reach $\$ 35$ billion in 2015. The overall picture shows major differences between countries and regions regarding consumer preferences (Nielsen 2015). The mediatisation of food scandals in the past decades has affected consumer confidence. In the case of baby foods, the focus of consumers and authorities on product safety leads companies to treat the safe production and marketing of these products with high sensitivity.

Consumer protection and food laws give consumers the rights to safe food and accurate information. The Hungarian consumer protection law (Act CLV of 1997) declares five consumer protection principles, of which the two most important ones are the protection of consumers' health and safety, and the right to consumer information. According to the Hungarian consumer protection law (2. §), 'a consumer is a natural person acting for his/her independent occupation and economic activity, who purchases, orders, receives, claims, and uses a product offer, and who is the addressee of the commercial communication'.

The manufacturer informs the consumers about the composition of a product through the product label, user and instruction manuals and distinctive signs. The purpose of such pieces of information is to give appropriate knowledge about the use or the composition of goods (Kovács 2013). According to Szúcs (2010), one of the simplest ways of providing information is to use food labels that provide not only quantitative, but also qualitative information to consumers in an easily comprehensible manner. The Regulation No. 1169/2011 on the provision of food information to consumers was passed in December 2011 by the European Union (EU). It was applicable in all EU member states, however, the provision of allergen information for pre- and non-packaged foods became mandatory only in December 2014. (The manufacturers were entitled to a grace period of 3 years to revise the contents of their food labels, to make sure that they conform to the regulation.) By the formerly mentioned legislation, it is necessary to provide adequate information on food products to ensure the high level of consumer health protection and to guarantee the consumers' right to information. The regulation reinforced the previous food labelling rules and laid down the mandatory indication of the products' nutritional value from December 2016. The mandatory particulars of food labels include the name of the food, the list of ingredients, the quantity of certain ingredients (e.g. that of additives and allergenic substances, any ingredient or processing aid derived from a substance or product causing allergies or intolerances, the country of origin, the net quantity of the food), a nutrition declaration, the expiration date, any special storage conditions, and the (business) name and postal address of the food producer (Friedrichné 2010). In this study, as mentioned earlier, we examine only the food labels of jarred baby foods.

Conscious consumers check food labels for ingredients at the time of purchase. Gintner's study (1999) reveals that consumers primarily focus on the amount of

Regional Statistics, Vol. 8. No. 1. 2018: 202-221; DOI: 10.15196/RS080110 
flavour enhancers, raising agents, food colourings, and stabilisers. The ingredients of baby foods are subject to stricter controls than those of any other foods, as the children's health condition, among others, depends on their nutrition that is their parents' responsibility.

While food labelling regulations are continuously evolving, only a few studies on baby food label preferences and usage have been published worldwide. Although the baby food production system is very safe in terms of ingredients and the production process, an inadequate food labelling system, low consumer involvement, or poor knowledge regarding the label information can jeopardise consumers' health. The absence of consumer behaviour studies related to baby food labels is also characteristic of the literature in Central and Eastern European countries.

\section{Role of food labels in the food consumer behaviour models}

Lehota (2001) categorised the factors that affect food consumer behaviour in the following groups: economic factors (price and income proportions), biological factors (perception, cognition, and illnesses), demographic factors, social factors (social stratification and family), psychological factors (personality, motivation, and attitudes), and cultural factors (traditions). Among the economic factors, we primarily focus on consumers' income, purchasing power, and the price of the products. The prices of baby foods considered in this study are relatively high, which implies that families with small children incur a high cost on their purchase. Concerning the biological factors, the flavour and composition of baby foods are critical; they determine not only the children's preferences, but also the edibility of foods. Nowadays food allergies and intolerances affect a lot of babies, and hence mothers consciously browse to collect information on ingredients used in these products. Demographic structural changes also affect a nation's nutritional status. Concerning the social factors, it must be noted that in our society there is an emphasis on adopting a healthy and conscious lifestyle, and consumers demand products that support such a lifestyle. We follow reference groups and family traditions in our lives, which also influence our food purchasing habits. Concerning the psychological factors, the values reflecting a healthy lifestyle are manifested in an attitude that motivates the development of our regular meals. Additionally, cultural factors, such as eating habits and traditions, fundamentally determine the consumers' behaviour.

The Pilgrim (1957) model was the first model in the literature that examined food consumption behaviour. It is based on three pillars (food properties, personal and socioeconomic factors) which influence consumers' food purchasing decisions. Concerning the food properties, nutrient characteristics and psychological effects of food predominate all other factors. The food properties in the Pilgrim model also

Regional Statistics, Vol. 8. No. 1. 2018: 202-221; DOI: 10.15196/RS080110 
include the sensory properties that have various physiological effects. An individual senses the visual stimulus induced by foods and reacts to them. When considering the psychological factors, it is essential to understand an individual's previous experience with a food product, his/her specific preferences, and the method employed to analyse the affective responses to food. Among the socioeconomic factors, price, brand, and availability are influential. Lehota (2001) and Szakály (2011) have revealed that the Pilgrim model is limited as the interactions between the factors are not fully covered. The Pilgrim model was improved by Shepherd (1990); Brávácz (2015) notes that the improved model emphasizes food characteristics, details person-related factors, and groups the socio-cultural and economic factors under the environmental factors. According to Miller and Cassady (2015), nutrition knowledge can support the use of information on food labels at least in the following three ways: it 1. motivates consumers to pay attention to the important information on the label and ignore marketing features, 2. helps consumers to understand the data on the label, and 3. encourages the use of information while making food choices.

Kempen et al. (2011) have revealed during their qualitative research that consumers use labels to assess the nutritional values, personal benefits, health features and quality of food products. Making a food choice is no longer considered a part of a routine shopping activity involving low risk, but as an activity requiring a high degree of involvement and hence resulting in a rational choice (Schiffman-Kanuk 2010). Health conscious consumers buy products that meet their specific nutritional needs as opposed to mass products (Panyor 2007). This factor raises the foundational question of our study: Is this the reason why there is a wide variety of baby foods on store shelves? We have to mention the concept of strategic foods, which is described by Szente et al. (2006) with the following three characteristics: their marketing involves a focus on the nutrient profile, they have distinct marketing features, and an increase in their annual consumption significantly exceeds the consumption of traditional foods. Based on this concept, the authors define three categories of foods: 1. functional foods, 2. organic foods, and 3. traditional and local foods. In the case of baby foods, only the first two categories are relevant and examined in our study.

Piskóti et al. (2006) state that functional foods have a beneficial effect on health and well-being. Functional foods can be defined as follows: They provide energy, contain vitamins, cure naturally, and strengthen the immune system. They have a positive effect on digestion - bringing it in balance - heart health, stress, and sleep (relaxation), strengthen bones and cartilages, and retard the aging process. Nagy (2010) draws attention to the role of mothers in promoting the adoption of functional foods and teaching their children how they may live and have a healthy diet. We prefer these foods of vegetable or animal origin to organic foods, which are produced, processed or imported under the statutory requirements of organic

Regional Statistics, Vol. 8. No. 1. 2018: 202-221; DOI: 10.15196/RS080110 
production and under the control of recognized inspection bodies (Maczák et al. 2011).

\section{Food labelling and searching for label information}

In 2011, the EU formulated a new law on food labelling (Regulation No. 1169/2011), with the aim of enhancing the overall information available for consumers. The excessive consumption of sugar, salt and (saturated) fats has led to an increase in the number of obese or diabetic people. According to Gyrd-Hansen and Kjaer (2015), health costs and reduced productivity of obese people can lead to a negative externality and to the bankruptcy of the healthcare system (Cawley-Meyerhoefer 2012, Cavaliere et al. 2017).

The individuals with multiple illnesses 'burden' the healthcare system since they are out of work for a longer or shorter time or have permanently exited the labour market due to their illnesses or reduced ability to work. Currently, the Hungarian employment policy is facing new challenges which suggest an increase in the shortage of labour. The main reason behind labour shortage is that the domestic wages are in Hungary lower in some professions (in healthcare, food service industry, services, etc.) than in Western Europe, and hence many employees work abroad. This is accompanied by the fact that, as per the employment status, the health condition of the Hungarian workforce is not adequate (Orosz-Kollányi 2016) and shows continued deterioration. Although we do not examine the reasons behind these phenomena in the present study, they may be interesting research questions in the future.

Miller and Cassady (2015) reviewed the labelling of foods and divided food label contents into the following three groups: nutrition facts, ingredients list, and claims. Concerning food label descriptions, the important information (such as nutritional data (WHO 2013) and the calorie content (Kiszko et al. 2014)) is indicated in various forms. However, this complex information many times poses a challenge to consumers in the selection of healthy foods (Nelson et al. 2014). In recent years, there has been a growing demand for foods that are rich in natural ingredients and free of additives as consumers believe that these products are healthier (Dickson-Spillman et al. 2011). In the EU, the European Food Safety Authority (EFSA) identifies some ingredients with ' $E$ ' numbers, consumers, however, often mistakenly consider them harmful and unhealthy.

Is labelling of foods enough to reform our lifestyle and consuming behaviour? The answer is not clear. According to Ollberding et al. (2010), labelling of foods itself is not enough to change consumer behaviour effectively. Nevertheless, dieticians can use food labelling as a motivating tool for preventing and treating obesity and chronic dietary illnesses. Pettigrew et al. (2017) draw attention to the nutritional values at the front of the food packs and to the novelty of the front-of-

Regional Statistics, Vol. 8. No. 1. 2018: 202-221; DOI: 10.15196/RS080110 
pack labels (FoPLs). According to Loureiro et al. (2012), there is a correlation between nutritional labels and the measure of decreasing obesity, particularly in the case of women. Does a focus on health play a significant role in influencing the baby food choice of mothers of infants? We also cover this aspect in the following.

Bandara et al. (2016), in their research, have proven that most consumers tend to look at labels during their purchases; the labels contain the name, food safety and sustainability certifications as well as the origin of the product, and the reputation of the brand. In the case of a product designed to meet special dietary needs, such as food allergy, meatless diet, diets of various religious groups, and sustainable diet (organic foods), product information can be found in the description on the back of the product or can be accessed by applications that are able to read quick response (QR) codes. Nevertheless, there are also consumers who are loyal to a particular brand or may not study product labels when performing routine shopping activities.

As mentioned above, labels have a significant influence on our food selection, which raises the following questions: What constitutes a good label? What does a good label contain? What should be its colours and fonts like? How can it highlight information? The primary aspects of label design are regulated by the legislation of a country; the relevant rules are uniform in the member states of the EU.

\section{Methodology}

To support the findings of the literature, we performed a questionnaire survey based on novel research conducted in Hungary. The data collection phase of the research took place in August and September 2017, by using the snowball method and searching targeted Facebook groups. The Google Forms questionnaire was filled in by the respondents online. The analysis was conducted using IBM SPSS Statistics Version 24. All data were processed anonymously. The questionnaire examined the purchasing habits of mothers with small children regarding ready-to-use baby foods and the characteristics of the labels of such foods. (The questionnaire survey was mirror translated into Romanian and filled in by 403 Romanian mothers in the same period. Their answers were then compared to those that were collected in the study conducted in Hungary (Hajdú et al. 2018).) Besides demographic data, the questionnaire contained 22 questions about the contents of baby food labels. We intended to measure the general consumer habits regarding jarred baby foods and to explore the causes of non-consumption. The following research questions were formulated:

RQ1: What are the motivations driving consumers' baby food choice?

RQ2: What are the main problems of baby food labelling?

RQ3: What is the most frequently searched information on a baby food label?

RQ4: Can we identify the information clusters based on the consumers' label reading behaviour?

Regional Statistics, Vol. 8. No. 1. 2018: 202-221; DOI: 10.15196/RS080110 


\section{Evaluation of results}

After cleaning and checking the collected data, we had information on 590 Hungarian mothers who had permanent residence in Hungary. The representativeness of the sample was verified based on the distribution of their residence, age and qualifications. In the phase of questionnaire completion, we omitted five responses from the sample because the mothers' permanent residence was not in Hungary.

Table 1

Demographic distribution of the sample, 2017

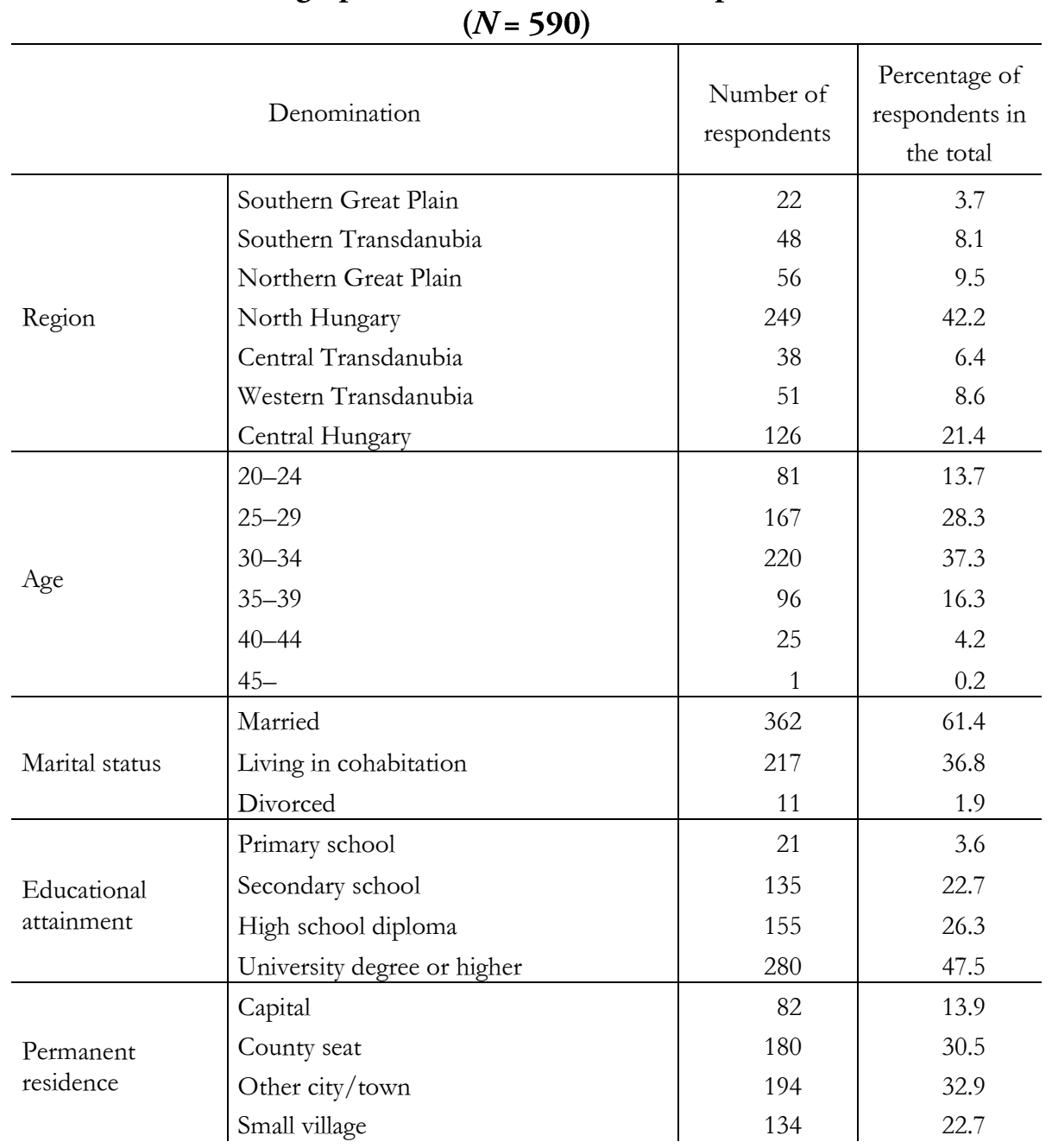

Note: Here and in the following tables, deviations from 100.0 result from rounding.

Source: Own calculation based on the 2017 survey results. 
In the sample, 1 person had 6 children, 2, 35, and 124 respondents had 4, 3, and 2 children, respectively, and 426 people had only 1 child. A total of 337 (57.1\%), $211(42.6 \%)$, and $2(0.3 \%)$ respondents started to feed their infants with jarred baby foods when the babies were 3-5 months, 6-8 months, and 9-11 months, respectively. The mothers purchased the following brands (several brands could be marked): Kecskeméti (380 persons), Unilever (351 persons), Hipp (328 persons), Hamanek (190 persons), DM (180 persons), Babydream (179 persons), and Rossmann (151 persons).

Fifty mothers having 1 child, 14 mothers having 2 children, and 3 mothers having 3 children did not try to give ready-to-use baby foods to their infants. Altogether, 523 mothers fed, but 67 mothers did not fed their babies with jarred baby foods. We asked the latter group of mothers about the reasons behind their abstaining from buying such products. By grouping their answers, the following aspects can be identified: 1 . They do not trust in the ingredients of the ready-to-use products available in stores; 2 . They have already given ready-to-use food to their children but the babies did not like it; 3 . They think the ready-to-use baby foods available in stores are very expensive; 4 . They do not buy ready-to-use products because of additives. Forty-eight mothers gave daily more than 1 jar of ready-to-use baby food to their children. Ninety-eight mothers fed their babies with 1 jar of ready-made baby food in a day, and a total of 165, 110, 50, and 52 mothers gave such foods to their children several times a week, once a week, once a month, and rarely, respectively.

\section{Demographic determinants of the baby food selection}

We examined the relationship between the permanent residence (region) and the purchases of ready-to-use baby foods. According to our null hypothesis, there is no correlation between them. We examined the null hypothesis with a cross table analysis and Chi-square statistics. The mothers that fed their children with jarred baby foods accounted for $88.6 \%$ of the Hungarian mothers taken part in the survey (while the remaining 11.4\% did not give such foods to their children).

The correlation between the two variables is given by the value of Pearson's Chi-square. The observed value of the indicator is 5.417 which is above the threshold of 0.05 at 0.000 significance level. Hence, we rejected the null-hypothesis. The results indicate that there is a significant relationship between the mothers' residence and their purchases of ready-to-use baby foods. We also examined the values of $\lambda$, Goodman and Kruskal's $\tau$ and the uncertainty coefficient; they indicate a decline in the error probability of the estimation. $\lambda$ contributes to our understanding of the country's baby food purchase with $0.0 \%$, Goodman and Kruskal's $\tau$ with $0.9 \%$, and the uncertainty coefficient with $0.5 \%$. This means that the mothers' residence in the indicated regions is not a good prediction variable of

Regional Statistics, Vol. 8. No. 1. 2018: 202-221; DOI: 10.15196/RS080110 
baby food purchases. There is a weak significant relationship between the two variables (the value of $\varphi$ is 0.096 , and Cramer's $V$ is 0.096).

Table 2

Cross tabulation of baby food consumption and the regions of Hungary, 2017

\begin{tabular}{|c|c|c|c|c|}
\hline \multirow[t]{2}{*}{ Region } & \multirow[t]{2}{*}{ Denomination } & \multicolumn{2}{|c|}{$\begin{array}{c}\text { Number and distribution of } \\
\text { the answers to the survey } \\
\text { question: 'Have you already } \\
\text { given ready-to-use baby } \\
\text { food to your baby?' }\end{array}$} & \multirow[t]{2}{*}{ Total } \\
\hline & & Yes & No & \\
\hline \multirow[t]{4}{*}{ Northern Hungary } & Number of the answers & 20 & 2 & 22 \\
\hline & $\begin{array}{l}\% \text { distribution of the 'Yes' and 'No' } \\
\text { answers in the region }\end{array}$ & 90.9 & 9.1 & 100.0 \\
\hline & $\begin{array}{l}\% \text { in the total number of the 'Yes' or } \\
\text { 'No' answers }\end{array}$ & 3.8 & 3.0 & 3.7 \\
\hline & $\%$ in the total number of the answers & 3.4 & 0.3 & 3.7 \\
\hline \multirow{4}{*}{$\begin{array}{l}\text { Northern Great } \\
\text { Plain }\end{array}$} & Number of the answers & 45 & 3 & 48 \\
\hline & $\begin{array}{l}\% \text { distribution of the 'Yes' and 'No' } \\
\text { answers in the region }\end{array}$ & 93.8 & 6.3 & 100.0 \\
\hline & $\begin{array}{l}\% \text { in the total number of the 'Yes' or } \\
\text { 'No' answers }\end{array}$ & 8.6 & 4.5 & 8.1 \\
\hline & $\%$ in the total number of the answers & 7.6 & 0.5 & 8.1 \\
\hline \multirow{4}{*}{$\begin{array}{l}\text { Southern Great } \\
\text { Plain }\end{array}$} & Number of the answers & 50 & 6 & 56 \\
\hline & $\begin{array}{l}\% \text { distribution of the 'Yes' and 'No' } \\
\text { answers in the region }\end{array}$ & 89.3 & 10.7 & 100.0 \\
\hline & $\begin{array}{l}\% \text { in the total number of the 'Yes' or } \\
\text { 'No' answers }\end{array}$ & 9.6 & 9.0 & 9.5 \\
\hline & $\%$ in the total number of the answers & 8.5 & 1.0 & 9.5 \\
\hline \multirow{4}{*}{$\begin{array}{l}\text { Southern Transdan- } \\
\text { ubia }\end{array}$} & Number of the answers & 213 & 36 & 249 \\
\hline & $\begin{array}{l}\% \text { distribution of the 'Yes' and 'No' } \\
\text { answers in the region }\end{array}$ & 85.5 & 14.5 & 100.0 \\
\hline & $\begin{array}{l}\% \text { in the total number of the 'Yes' or } \\
\text { 'No' answers }\end{array}$ & 40.7 & 53.7 & 42.2 \\
\hline & $\%$ in the total number of the answers & 36.1 & 6.1 & 42.2 \\
\hline \multirow{4}{*}{$\begin{array}{l}\text { Western Transdan- } \\
\text { ubia }\end{array}$} & Number of the answers & 36 & 2 & 38 \\
\hline & $\begin{array}{l}\% \text { distribution of the 'Yes' and 'No' } \\
\text { answers in the region }\end{array}$ & 94.7 & 5.3 & 100.0 \\
\hline & $\begin{array}{l}\% \text { in the total number of the 'Yes' or } \\
\text { 'No' answers }\end{array}$ & 6.9 & 3.0 & 6.4 \\
\hline & $\%$ in the total number of the answers & 6.1 & 0.3 & 6.4 \\
\hline
\end{tabular}

Regional Statistics, Vol. 8. No. 1. 2018: 202-221; DOI: 10.15196/RS080110 


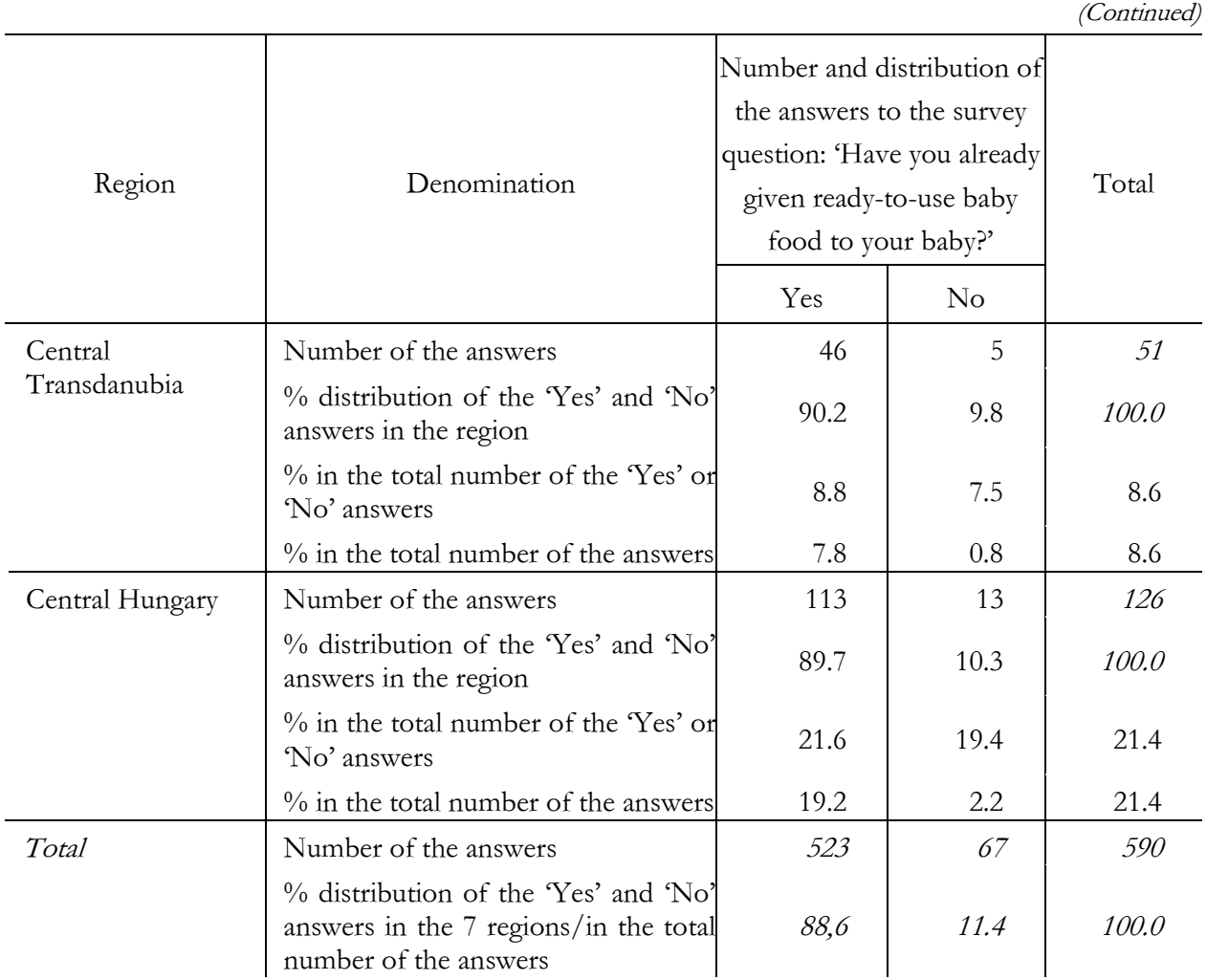

Source: Own calculation based on the 2017 survey results.

We also aimed to explore the relationship between the settlement types the mothers live in and their purchases of jarred baby foods. We examined the nullhypothesis (there is no correlation between settlement types and the purchases of ready-to-use baby foods) with a cross table analysis and Chi-square statistics. We assumed that people living in villages did not give ready-to-use baby foods, which can be bought in shops, to their children because they produced vegetables and fruits themselves in their backyard garden and prepared food from these for their infants. Conversely, $79.1 \%$ of the mothers in the sample, living in villages buy jarred baby foods for their children. Additionally, $92.7 \%$ of the mothers living in the capital, $88.9 \%$ of the mothers living in county seats, and $93.3 \%$ of the mothers living in other cities/towns give such foods to their children.

The correlation between the two variables is given by Pearson's Chi-square. The value of the observed indicator is $17.6(d f=3)$ which exceeds the threshold value of 0.05 at the 0.000 significance level. Hence, we rejected the null-hypothesis: the results show that there is a significant relationship between the type of settlement and purchases of ready-to-use baby foods. The knowledge of the

Regional Statistics, Vol. 8. No. 1. 2018: 202-221; DOI: 10.15196/RS080110 
settlement type improves our estimate for baby food purchases by $3.2 \%$, according to the uncertainty coefficient. The significance level is 0.000 in all cases. We also examined the values of $\lambda$, Goodman and Kruskal's $\tau$ and the uncertainty coefficient. The $\lambda$ is not significant (0.019). There is a weak significant relationship between the two variables (value of $\varphi$ is 0.0173 , and Cramer's $V$ is 0.173). Additionally, the predictive ability of the independent variable (settlement type) is very low, and hence it is probable that other variables also play a role in promoting the purchase of ready-to-use baby foods.

Table 3

\section{Cross tabulation of the type of settlement and baby food consumption, 2017}

\begin{tabular}{|c|c|c|c|c|}
\hline \multirow[t]{2}{*}{$\begin{array}{c}\text { Type of } \\
\text { settlement }\end{array}$} & \multirow[t]{2}{*}{ Denomination } & \multicolumn{2}{|c|}{$\begin{array}{l}\text { Number and } \\
\text { distribution of the } \\
\text { answers to the survey } \\
\text { question: 'Have you } \\
\text { already given ready- } \\
\text { to-use baby food to } \\
\text { your baby?' }\end{array}$} & \multirow[t]{2}{*}{ Total } \\
\hline & & Yes & No & \\
\hline \multirow[t]{4}{*}{ Capital } & Number of the answers & 76 & 6 & 82 \\
\hline & $\begin{array}{l}\% \text { distribution of the 'Yes' } \\
\text { and 'No' answers in the type } \\
\text { of settlement }\end{array}$ & 92.7 & 7.3 & 100.0 \\
\hline & $\begin{array}{l}\% \text { in the total number of the } \\
\text { 'Yes' or 'No' answers }\end{array}$ & 14.5 & 9.0 & 13.9 \\
\hline & $\begin{array}{l}\% \text { in the total number of the } \\
\text { answers }\end{array}$ & 12.9 & 1.0 & 13.9 \\
\hline \multirow[t]{4}{*}{ Country seat } & Number of the answers & 160 & 20 & 180 \\
\hline & $\begin{array}{l}\% \text { distribution of the 'Yes' } \\
\text { and 'No' answers in the type } \\
\text { of settlement }\end{array}$ & 88.9 & 11.1 & 100.0 \\
\hline & $\begin{array}{l}\% \text { in the total number of the } \\
\text { 'Yes' or 'No' answers }\end{array}$ & 30.6 & 29.9 & 30.5 \\
\hline & $\begin{array}{l}\% \text { in the total number of the } \\
\text { answers }\end{array}$ & 27.1 & 3.4 & 30.5 \\
\hline \multirow[t]{4}{*}{ Other city/town } & Number of the answers & 181 & 13 & 194 \\
\hline & $\begin{array}{l}\% \text { distribution of the 'Yes' } \\
\text { and 'No' answers in the type } \\
\text { of settlement }\end{array}$ & 93.3 & 6.7 & 100.0 \\
\hline & $\begin{array}{l}\% \text { in the total number of the } \\
\text { 'Yes' or 'No' answers }\end{array}$ & 34.6 & 19.4 & 32.9 \\
\hline & $\begin{array}{l}\% \text { in the total number of the } \\
\text { answers }\end{array}$ & 30.7 & 2.2 & 32.9 \\
\hline
\end{tabular}

Regional Statistics, Vol. 8. No. 1. 2018: 202-221; DOI: 10.15196/RS080110 


\begin{tabular}{|c|c|c|c|c|}
\hline \multirow[t]{2}{*}{ Type of settlement } & \multirow[t]{2}{*}{ Denomination } & \multicolumn{2}{|c|}{$\begin{array}{c}\text { Number and } \\
\text { distribution of the } \\
\text { answers to the survey } \\
\text { question: 'Have you } \\
\text { already given ready-to- } \\
\text { use baby food to your } \\
\text { baby?' }\end{array}$} & \multirow[t]{2}{*}{ Total } \\
\hline & & Yes & No & \\
\hline \multirow[t]{4}{*}{ Village } & Number of the answers & 106 & 28 & 134 \\
\hline & $\begin{array}{l}\% \text { distribution of the 'Yes' and } \\
\text { 'No' answers in the type of set- } \\
\text { tlement }\end{array}$ & 79.1 & 20.9 & 100.0 \\
\hline & $\begin{array}{l}\% \text { in the total number of the } \\
\text { 'Yes' or 'No' answers }\end{array}$ & 20.3 & 41.8 & 22.7 \\
\hline & $\begin{array}{l}\% \text { in the total number of the } \\
\text { answers }\end{array}$ & 18.0 & 4.7 & 22.7 \\
\hline \multirow[t]{2}{*}{ Total } & Number of the answers & 523 & 67 & 590 \\
\hline & $\begin{array}{l}\text { \% distribution of the 'Yes' and } \\
\text { 'No' answers in the type of set- } \\
\text { tlement/in the total number of } \\
\text { the answers }\end{array}$ & 88,6 & 11.4 & 100.0 \\
\hline
\end{tabular}

Source: Own calculation based on the 2017 survey results.

We also used the above method for examining the connection between the ages of mothers and their purchasing habits regarding jarred baby foods. The value of Pearson's Chi-square was $16.404(d f=5)$ which exceeded the threshold value of 0.05 at the 0.000 significance level, showing a significant correlation between the two variables. However, their relationship is weak (the value of $\varphi$ is 0.167 , and Cramer's $V$ is 0.167$)$. The examination of various age groups of the sample shows interesting results: $97.5 \%$ of the mothers aged 20 to 24 years, $89.2 \%$ of the mothers aged 25 to 29 years, $82.7 \%$ of the mothers aged 30 to 34 years, $91.7 \%$ of the mothers aged 35 to 39 years, $96 \%$ of the mothers aged 40 to 44 years and the remaining 1 mother in the age group of 45 years and over give/have already given ready-to-use baby foods to their children. Consequently, it can be stated that especially the very young and the elder mothers turn their attention towards ready-to-use products which are available in shops. (Elder mothers probably have more children, and younger mothers may not have enough experience in preparing baby food, therefore, to save time they choose the more comfortable, time-saving solution.)

Regional Statistics, Vol. 8. No. 1. 2018: 202-221; DOI: 10.15196/RS080110 


\section{Baby food selection and label preferences}

We aimed to explore the relationship between the type of settlement mothers live in and the decision-making aspects of purchasing baby foods. To this end, the mothers had to evaluate the following aspects on a scale from 1 to 5 (Questionnaire question: 'What is your reason for buying ready-to-use baby food?'): 1 . to increase my child's nutritional value intake; 2 . to improve my child's health condition; 3 . due to lack of time; 4. for convenience purposes; 5 . to feed my child when travelling, and 6. to make my child's diet diversified. We considered the settlement types to be independent variables and set the decision-making aspects of purchasing baby foods as the dependent variable. From the statistical methods, we chose the analysis of variance (ANOVA) to be applied, which examines the effect of one or more independent variables on one or more dependent variables. The condition for the applicability of variance analysis is that the dependent variable have normal distribution and the variance homogeneity (deviation homogeneity) is fulfilled. In the sample, the deviation homogeneity could not be achieved, and thus we did not continue the analysis.

Average scores given by the respondents to six decision-making aspects, 2017

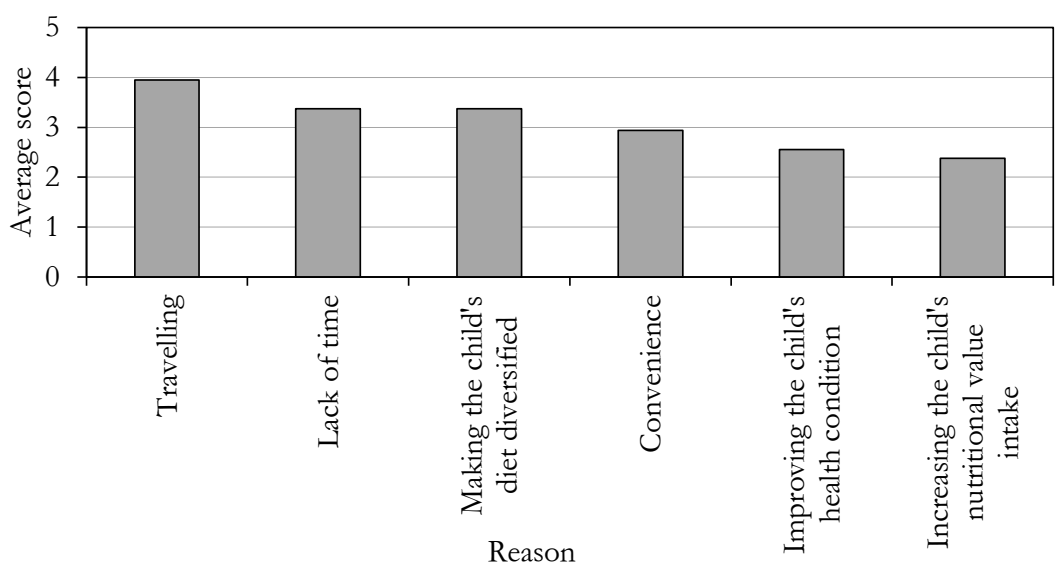

Source: Own calculation based on the 2017 survey results.

Travelling was the most valued reason for purchasing jarred baby foods; the lack of time received, on an average, 3.377 scores, and convenience, which is a similar aspect, 2.941 scores. To the reason of making the child's diet diversified, on an average, 3.372 average scores were given by the Hungarian mothers.

The packaging, design, and price, the absence of artificial colourings, the brand, and the presentation of labelling have less influence on the purchase decisions of mothers. However, the product composition, the information on the label, the

Regional Statistics, Vol. 8. No. 1. 2018: 202-221; DOI: 10.15196/RS080110 
flavour, and the presence of ingredients from organic farming have more influence on their purchase decisions (the significance level of these were less than 0.05).

Figure 2

Average scores given by the respondents to ten baby food features, 2017

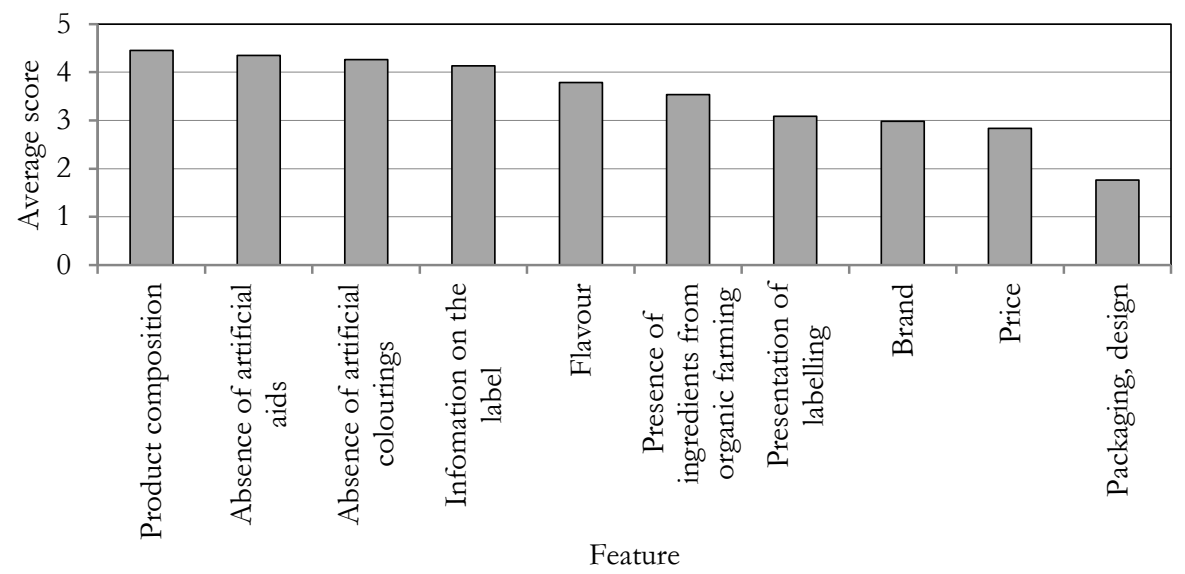

Source: Own calculation based on the 2017 survey results.

The mothers gave the highest scores to the labels that gave useful information (4.1) and to those that guaranteed the quality and safety of foods (3.3). The labels that prevented fraud of information (2.7), and the ones that were not easy to understand (2.1) or containing a lot of information (1.9) did not receive high scores.

We aimed to explore whether there was a relationship and what kind of relationship existed between the choice of mothers living in various settlement types as their permanent residence and the information on the labels of baby foods. For the mothers, the type of settlement is not relevant. It was found that the mothers pay more attention to the careful reading of ingredients, shelf life, recommended age, and nutrient composition on the labels. Unfamiliar expressions, tiny fonts, unorganised information, incorrect translations were rated with extremely low points of around 2 , on an average. The significance level was acceptable for the following factors: list of ingredients (0.03), illustrations (0.04), and shelf life (0.04). The other information on the labels has extremely high significance level. Illustrations and colourings influence shopping, especially if the child is older and has the right to choose. There are significant differences between the packaging and colourings of the various products. For example, the Unilever baby foods brand has the illustration of Winnie the Pooh and his friends, which attracts young children rather than their mothers. The respondents also evaluated the list of ingredients, and gave, on an average, 4.6 scores to this factor. The highlighted appearance of allergens received, on an average, 4.3 scores.

Regional Statistics, Vol. 8. No. 1. 2018: 202-221; DOI: 10.15196/RS080110 


\section{Factor analysis of the food label preferences}

We performed a factor analysis on the following question: 'To what extent do you pay attention to the information on baby food labels?' A total of 106 mothers do not read the labels carefully, while 484 mothers read them with attention. Before performing the calculations, we checked whether the data were correct; the variables followed normal distribution. We worked with metric and non-dummy variables and found that multicollinearity prevailed between them. The sample is homogeneous, and the sample size is over 100; hence, after the fulfilment of the necessary conditions, we regarded the accomplishment of the head component analysis as acceptable. The test coefficients had to be decorrelated in pairs. This was performed through the Kaiser-Meyer-Olkin indicator. The closer the indicator is to the value of 1 , the more applicable the analysis is to the variable. The Bartlett's test showed the same results. The value of the Kaiser-Meyer-Olkin indicator is 0.825 that is quite good and reliable. Hence, the main component analysis was accepted for the variable set (Sajtos-Mitev 2007).

Table 4

The Kaiser-Meyer-Olkin indicator and the results of the Bartlett's test

\begin{tabular}{c|c|c}
\hline \multicolumn{2}{c|}{ Kaiser-Meyer-Olkin measure of sampling adequacy } & 0.825 \\
\hline \multirow{3}{*}{ Bartlett's test of sphericity } & Chi-square & 2731.635 \\
$d f$ & 78 \\
Significance & 0.000
\end{tabular}

Note. The results are based on the answers given to the question: 'To what extent do you pay attention to the following information on baby food labels?'

Source: Own calculation based on the 2017 survey results.

The scree plot figure helped to decide on the number of factor groups. The breakpoint could be observed after the third variable number, and thus we tried to create three factors. The component matrix did not fit well because the variables did not fit into the factors, and hence the data had to be rotated. As a result, we received a rotated component matrix. We performed the rotation using the variance maximization (varimax) method by Kaiser's normalization. The value of the explained variance must be at least $60 \%$; in this case, it is $60.1 \%$. A variable is a member of a factor if the weight of the factor is at least 0.5 .

Based on the obtained factors, the following three groups were specified: 1. those who only deal with general product information; 2 . those whose purchases are affected primarily by the content of the products; and 3 . those who mainly pay attention to the appearance of the labels.

For selecting the important aspects of baby food labels, we performed another factor analysis. Here the value of the Kaiser-Meyer-Olkin indicator is 0.771 .

Regional Statistics, Vol. 8. No. 1. 2018: 202-221; DOI: 10.15196/RS080110 
We performed the rotation using varimax (variance-maximization) by Kaiser's normalization. In this case, the explained variance value is $62.7 \%$. Here again, a variable is a factor member if the weight of the factor is at least 0.5 .

Table 5

The rotated component matrix of baby food label information preferences

\begin{tabular}{l|c|c|c}
\hline \multirow{2}{*}{ Variable (baby food label information) } & \multicolumn{3}{|c}{ Factor } \\
\cline { 2 - 4 } & 1 & 2 & 3 \\
\hline Daily recommended quantity & 0.662 & 0.193 & 0.282 \\
Shelf life & 0.821 & 0.188 & 0.053 \\
Storage conditions & 0.866 & 0.188 & 0.094 \\
Consumption suggestions & 0.829 & 0.214 & 0.151 \\
Recommended age & 0.485 & 0.185 & 0.108 \\
List of ingredients & 0.194 & 0.698 & -0.253 \\
Indication of allergens & 0.237 & 0.663 & -0.011 \\
Nutritional composition & 0.293 & 0.661 & 0.088 \\
Indications of special quality & 0.064 & 0.764 & 0.276 \\
(bio, fair trade) & 0.200 & 0.611 & 0.237 \\
Place of origin & 0.195 & 0.031 & 0.891 \\
Illustrations & 0.153 & 0.024 & 0.881 \\
Colourings & 0.149 & 0.350 & 0.430 \\
Weight & & &
\end{tabular}

Note: In the table, the three colours represent different factors.

Source: Own calculation based on the 2017 survey results.

The rotated component matrix of baby food features

Table 6

\begin{tabular}{l|r|r|r}
\hline \multirow{2}{*}{\multicolumn{1}{c|}{ Variable (baby food feature) }} & \multicolumn{3}{c}{ Factor } \\
\cline { 2 - 4 } & \multicolumn{1}{c}{1} & \multicolumn{1}{c}{2} & \multicolumn{1}{c}{3} \\
\hline Product composition & 0.734 & 0.332 & -0.138 \\
Information on the label & 0.698 & 0.287 & -0.085 \\
Food ingredients from organic farming & 0.669 & -0.165 & 0.373 \\
Absence of artificial colourings & 0.887 & 0.031 & 0.090 \\
Absence of artificial aids & 0.896 & 0.021 & 0.104 \\
Price & -0.104 & 0.698 & 0.125 \\
Brand & 0.135 & 0.696 & 0.153 \\
Flavour & 0.337 & 0.562 & 0.093 \\
Packaging and design & -0.023 & 0.100 & 0.860 \\
Presentation of labelling & 0.121 & 0.317 & 0.676
\end{tabular}

Note: In the table, the three colours represent different factors.

Source: Own calculation based on the 2017 survey results.

Regional Statistics, Vol. 8. No. 1. 2018: 202-221; DOI: 10.15196/RS080110 
Based on the obtained factors, the following three groups were formed: 1. conscious consumers who pay attention to the information on the product labels; 2. consumers who focus on price or loyal to a special brand; and 3. consumers who base their selection on the appearance of the product.

We also asked the mothers if they found any error in the Hungarian translation of the labels of the foreign products or any difference between the information included in the translated labels and that of the original ones (in a foreign language). In the case of a product, 29 people felt that the information indicated on the foreign language label differed from that of the Hungarian translation. Therefore, 26 of them stopped buying that product. Several respondents experienced that there was a difference between the original and the translated versions of the labels regarding age recommendation, and many people had problems with the translation of 'Eiweiss' (protein), too. Additionally, in some cases, the Hungarian labels did not indicate the common name of the fish species among ingredients and did not provide information on added sugar either as compared with the original labels. Some people mentioned that the original foreign (German) labels contained more information than the Hungarian ones.

\section{Conclusions}

Nourishment constitutes an essential element of the trendy health-conscious lifestyle. Unfortunately, there are many people who can only consume special foods due to their various allergies or food intolerances. Thus, information on product labels is very important as it facilitates the identification of product components. While earlier food purchases were nothing more than a routine selection of products, nowadays they are the question of rationality. For example, a lactose or gluten-sensitive person will make a rational decision when he/she prioritises lactoseor gluten-free products while purchasing his/her daily use food items.

Our eating habits are influenced by our flavour preferences developed during childhood. Food sensitivity may also develop at a very young age (during infancy). Therefore, the selection of superior quality baby food products is especially important. Based on the answers given by the respondents of our survey to the research questions, we found that the main motivations driving customers' choice of jarred baby foods are feeding infants while travelling, lack of time to prepare baby foods at home, and making the children's diet diversified. Those mothers who do not use ready-to-use baby foods trust in their own choice of ingredients and prepare food at home for their children (RQ1). The main problems with the labelling are the missing information, and in certain situations the ambiguous translations and the small letters (RQ2). According to our research, $88.6 \%$ of the Hungarian mothers taken part in the survey buy ready-to-use baby foods for their

Regional Statistics, Vol. 8. No. 1. 2018: 202-221; DOI: 10.15196/RS080110 
children and pay attention especially to the ingredients and shelf life of such products (RQ3). Based on the extent of paying attention to product label information, the following groups of mothers could be formed: 1. those who only deal with information on ready-to-use baby food products; 2 . those who are attentive primarily to the product composition; and 3. those who mainly give regard to the appearance of the product (RQ4).

It is surprising that the foreign-language descriptions of the products manufactured abroad are often more detailed than their Hungarian translations. Therefore, we recommend paying more attention to the quality of such translations in the future.

\section{Acknowledgement}

The authors wish to thank Zsuzsa Săplăcan for her useful advice on the development of the questionnaire structure.

\section{REFERENCES}

Bandara, B. E. S.-DE Silva, D. A. M.-Maduwanthi, B. C. H.-WArunasinghe, W. A. A. (2006): Impact of food labeling information on consumer purchasing decision: with special reference to faculty of agricultural sciences Procedia Food Science 6: 309-313. https://doi.org/10.1016/j.profoo.2016.02.061

BRÁVÁCZ, I. (2015): Az élelmiszerfogyasztói magatartás két dimenziója: az egészség- és a környezettudatosság. PhD-értekezés, Gödöllő. https://szie.hu//file/tti/ archivum/Bravacz_Ibolya_ertekezes.pdf (downloaded: 14 September 2017)

Cavaliere, A.-DE MARChi, E.-BANTERLE, A. (2017): Investigation on the role of consumer health orientation in the use of food labels Public Health 147: 119-127 https://doi.org/10.1016/j.puhe.2017.02.011

CAWLEy, J.-MeYerhoefer, C. (2012): The medical care costs of obesity: An instrumental variables approach Journal of Health Economics 31 (1): 219-230. https://doi.org/10.1016/j.jhealeco.2011.10.003

DiCKSON-SpILlmanN, M.-SiEgrist, M.-Keller, C. (2011): Attitudes toward chemicals are associated with preference for natural food Food Quality and Preference 22 (1): 149-156. https://doi.org/10.1016/j.foodqual.2010.09.001

Friederichné, I. T. (2010): Fogyasztói érdekvédelem. http://www.viszki.sulinet.hu/ tananyagtar/gazdasagi/friedrichne/fe.pdf (downloaded: 7 August 2017)

GINTNER, Z. (1999): Élelmiszer vagy élelmiszeripari termék? Vegyem vagy ne vegyem? Egyem vagy ne egyem? Fogyasztóvédelmi füzetkék. http://adatbazis.okotars.hu/sites/default/files/elelmiszerbiztonsag.pdf

GYRD-HANSEN, D-KJAER, T. (2015): Government interventions to aid choice: Help to selfhelp or paternalism? Health Policy 119 (7): 874-881. https://doi.org/10.1016/j.healthpol.2015.02.001

Regional Statistics, Vol. 8. No. 1. 2018: 202-221; DOI: 10.15196/RS080110 
HAJDÚ, N.-LIPTÁK, K.-SĂPLĂCAN, ZS. (2018): Comparative analysis of baby food labelling in Hungary and in Romania: Consumers' perspective Amfiteatru Economic 20 (47): 62-83. https://doi.org/10.24818/EA/2018/47/62

Kempen, E.-Bosman, M.-Bouwer, C.-Klein, R.-VAn Der Merwe, D. (2011): An exploration of the influence of food labels on South African consumers' purchasing behaviour. International Journal of Consumer Studies 35 (1): 69-78. https://doi.org/10.1111/j.1470-6431.2010.00928.x

Kiszko, K. M.-MartineZ, O. D.-Abrams, C.-Elbel, B. (2014): The influence of calorie labeling on food orders and consumption: A review of the literature Journal of Community Health 39 (6): 1248-1269. https://doi.org/10.1007/s10900-0149876-0

KovÁCs, I. (2013): Társadalmilag felelős fogyasztás vizsgálata Területi Statisztika 53 (4): 372-386.

LEHOTA, J. (2001): Marketingkutatás az agrárgazdaságban Mezőgazda Kiadó, Budapest.

LOUREIRO, M. L.-Yen, S. T.-NAYGA, R. M. (2012): The effects of nutritional labels on obesity Agricultural Economics 43 (3): 333-342. https://doi.org/ 10.1111/j.1574-0862.2012.00586.x

MACZÁK, B.-MÉSZÁROS, L.-SZERLETICSNÉ TúRI, M.-SZEITZnÉ SZABÓ, M. (2011): Az ökológiai („bio”) élelmiszerek élelmiszer-biztonsági értékelése az európai uniós adatok tükrében. Biokontroll. https://www.biokontroll.hu/az-oekologiaiqbioq-elelmiszerek-elelmiszer-biztonsagi-ertekelese-az-europai-unios-adatoktuekreben (downloaded: 14 September 2017)

Miller, L. M. S.-CASSADY, D. L. (2015): The effects of nutrition knowledge on food label use. A review of the literature Appetite 92: 207-216. https://doi.org/10.1016/j.appet.2015.05.029

NAgY, SZ. (2010): Functional food marketing - The Hungarian market case Theory Methodology and Practice: Club of Economics in Miskolc 5 (1): 43-49.

Nelson, D.-Graham, D.-HARnACK, L. (2014): An objective measure of nutrition facts panel usage and nutrient quality of food choice Journal of Nutrition Education and Behavior 46 (6): 589-594. https://doi.org/10.1016/j.jneb.2014.04.296

NIELSEN (2015): Oh, baby! Trends in the global baby food and diaper markets http://www.nielsen.com/content/dam/nielsenglobal/de/docs/Nielsen\%20Glo bal\%20Baby\%20Care\%20Report\%20-\%20August\%202015.pdf (downloaded: 28 August 2017)

Ollberding, N. J.-Wolf, R. L.-CONTENTO, I. (2010): Food label use and its relation to diatery intake among US adults Journal of American Dietetic Association 110 (8): 1233-1237. https://doi.org/10.1016/j.jada.2010.05.007

Orosz, É.-KOLLÁNYI, Zs. (2016): Egészségi állapot, egészség-egyenlötlenségek nemzetközi összehasonlitásban. Társadalmi Riport 2016, Tárki, Budapest.

PANYOR, Á. (2007): A különleges élelmiszerek piacnövelési lehetóségei megkérdezések tükrében, Ph.D. értekezés, Budapesti Corvinus Egyetem. http://phd.lib.unicorvinus.hu/161/1/panyor_agota.pdf (downloaded: 25th August 2017)

Regional Statistics, Vol. 8. No. 1. 2018: 202-221; DOI: 10.15196/RS080110 
Pettigrew, S.-Talati, Z.-Miller, C.-Dixon, H.-Kelly, B.-Ball, K. (2017): The types and aspects of front-of-pack food labelling schemes preferred by adults and children Appetite 109: 115-123. https://doi.org/10.1016/j.appet.2016.11.034

PILGRIM, F. J. (1957): The component of food acceptance and their measurement The American Journal of Clinical Nutrition 5 (2): 171-175. https://doi.org/10.1093/ajcn/5.2.171

PiskótI, I.-NAGY, Sz.-KovÁCS, A. T. (2006): Fogyasztói magatartás a funkcionális élelmiszerek piacán Marketing Kaleidoszkóp http://real.mtak.hu/24720/1/ fogyasztoi_magatartas_a_funkcionalis_elemiszerek_piacan_Marketing_Kaleidosz kop_2006_u.pdf (downloaded: 14 September 2017)

Regulation (EU) No 1169/2011 of the European Parliament and of the Council of 25 October 2011 on the provision of food information to consumers https://ec.europa.eu/food/safety/labelling_nutrition/labelling_legislation_en (downloaded: 04.07.2017)

Sajtos, L.-Mitev, A. (2007): SPSS kutatási és adatelemzési kézikönyv. Alinea Kiadó, Budapest.

SCHIFFMAN, L.-KAnUK, L. (2010): Consumer Behaviour 10th Edition Pearson, London.

SHEPHERD, R. (1990): Overview of factors influencing food choice British Nutrition Foundation, Nutrition Bulletin 15 Supplement (1): 12-30.

SZAKÁLY, Z. (2011): Táplálkozásmarketing Mezőgazda Kiadó, Budapest.

SZENTE, V.-SZÉLES, GY.-SZAKÁLY, Z. (2006): Az élelmiszer-fogyasztói magatartástrendek vizsgálata, kiemelt figyelemmel a stratégiai élelmiszerekre Élelmiszer, Táplálkozás és Marketing 3 (2): 3-11.

SzŰCS, R. (2010): A gyermekkori elhízás és az élelmiszercímke összefüggéseinek marketing szempontú vizsgálata Gazdálkodás 54 (7): 773-777.

WHO (2013): World Health Statistics 2013 (downloaded: 26 September 2017) http://www.who.int/gho/publications/world_health_statistics/2013/en

Regional Statistics, Vol. 8. No. 1. 2018: 202-221; DOI: 10.15196/RS080110 